\title{
The Concept of Economic Development-A Pillar of National Security
}

\section{Măndescu Ionel*}

\author{
University "Lucian Blaga” of Sibiu, România.
}

*Correspondence E-mail: ionut_mandescu@yahoo.com

\begin{abstract}
The article relates to the existing connection between the economic development concept and the national security, stating the fact that a healthy economic development insures an economic and social security, promoting the national interest in sustaining the democratic institutions, therefore leading to the development of prosperity and national security. The economic development, implying economic growth, is a multidimensional concept, supporting the idea of change and transformation of economic structures, moreover the idea of increased standard of living and increased quality of living. Agreeing with the economist Francois Perroux, we state the idea that no progress should be called economic or social progress if it diminishes the chances of human progress. Although different, the two concepts are the result of social development, aiming to the same goal, the improvement of human condition and standard of living. Nowadays, Romania finds itself in the middle of an economic crisis mainly due to the external economic environment. The healthy solution for Romania's exit from this widening crisis remains an economic development able to attract strategic investments, create work places and increase the production of resources for social protection. Romania's national security can be sustained by an economic development that can assure citizens' economic prosperity, legality and social and politic stability.
\end{abstract}

Keywords: Competitiveness, Economic development, Economic progress, National security, The European Union.

\section{Introduction}

By beginning with Eminescu's concept of general positive continuity of national economies, brilliantly synthesized in his verse "Past and future are two sides of the same sheet", we may judge that the current situation of the Romanian economy has been determined and conditioned by the country's distant or recent past. At the same time, this state represents the initial condition - either favorable or restrictive - of both outlining the future of Romanian economy and society, as well as the concrete way in which it manifests itself in different periods of time. The Romanian people have definitely opted for the market economy and its functioning mechanism. The December 1989 revolution helped them to quickly, almost instantaneously, understand that the economic system based on the absolute monopoly of the "socialist" state ownership had led to bankruptcy, that the economic system of demand could no longer ensure the orientation of the nation's creative energies on their normal course and to their ultimate purpose: satisfying their unlimited and continuously diversifying needs. At present, a strong, performing, competitive, macro-economically stable economy, dynamic in relation to the level of growth and adaptability of integral demand and globalization represents an important pillar of national security, because it ensures the conditions of economic and social security, the interest of the majority of the population in order that the Măndescu Ionel et. al. | July.-Aug. 2012 | Vol.1 | Issue 4|130-132 democratic institutions be upheld as well as the necessary base for the promotion of initiatives aiming at national prosperity and security.

\section{Conceptual Specifications Concerning National Security}

National security is the state of the nation, of social communities, of the citizens, which is founded on economic prosperity, legality, balance and socio-political stability, expressed through order of law and ensured through economic, political, social, judicial, military and intelligence policies or of any other kind, all in the purpose of the undeterred exercise of civilian rights and liberties, the full manifestation of decisionmaking freedom and the action of the state, its fundamental attributes and the quality of the international law.

\section{Economic Development}

Economic development simultaneously comprises the quantitative, qualitative and structural aspects of the economic evolution, in correlation with the demographic evolution and general human problems, as well as the evolution of economic balance. Economic growth emphasizes the quantitative side of economic development, especially the production of goods and services, while the economic development, besides the economic changes of the standard of living, the way of living, thinking and behaving, of the 
efficient use of national economic resources and of functional mechanisms of the economic system. The main idea which defines economic development is change, transformation of economic structures, of the behavior of the economic system and the relation between human activities and the surrounding environment. The concept of economic development is multidimensional. Firstly, economic development implies in itself economic growth; there is no process of economic development without the growth of long term macro-economic results. However, in order to become a process of economic development, growth must be accompanied by economic qualitative structural transformations in the way of living and in the level of income of people. The relation between economic growth and development is seen from part to whole: economic growth - economic developmenteconomic progress - social progress. Secondly, economic development has a larger historic connotation; it catches the process whereby the economy of human society passes from an inferior form of evolution to a superior one, including the numerous temporary oscillations determined by various historic circumstances. Economic development, unlike economic growth designates the new technical economic and socio-economic relations which appear in the process of growth. Thirdly, economic development may be defined strictly speaking as the development of production factors, respectively the development of the main economic components within the framework of state-national space, such as: the development of material infrastructure, ensuring optimum conditions on a micro and macro-economic level concerning the combination of production factors, valuing the advantages of specializing the combination and cooperation between economic agents, development of stable economic fluxes between sectors and regions, the improvement of internal cohesion of the national economic space, the development and quality of commercial activities both internal and external, financial and banking activities etc. Fourthly, the notion of economic development refers to the difference between the progress in relations of economic agents and their economic environment (micro, macro and pan-economic) to not only technical but also social and psychological structures of production and the economy in their totality. This way of conceiving economic development offers the possibility of theory and practice to approach directly the basic phenomena of economic reality and the means of making it more dynamic, which are limited to the notion of economic and social progress.
The Relation between Economic Development and Economic Progress

Essentially, the economic progress can be found in the qualitative shift of the content factors of production and of relations in the economic life, in order to adapt the economy of demands of social progress at a certain stage in history, in a country or on a worldwide scale. At the same time, economic progress is a historical process of promoting national economy from an inferior to a superior level which manifests itself especially through the increase in the productivity of work, the increase in the absolute and relative level of macro-economic indicators (assessed depending on the number of inhabitants), the increase in conditions of modernization of all national economic structures (technological, branch, sector and zone, commercial and financial, etc.)The central process which structures economic progress also constitutes economic development, its contribution to the improvement of human living conditions. From this point of view, the economic progress is at the same time a social one. Economist François Perroux quite fairly considers that no progress deserves the attribute economic if it diminished the chances of humans developing. Conversely, no progress could be a social one if it did not give each person the means to maintain a human status of living. The unbreakable interdependence between economic growth and development, made visible through the mutual effects of accumulation and drive, gives the two processes certain common characteristics:

- They are the result of general development in society at a given time, but also the condition of a new social development;

- They have the goal of putting certain mechanisms in motion whereby the whole structure of the national economy is improved;

- They are simultaneously endogenous and exogenous variables of the economic system;

- They have the same goal - the improvement of the human condition, of the standard of living and of the quality of human lives.

\section{The State of Romanian Economy beyond Theoretic Concepts}

In 2012 Romania faced a deep economic and financial crisis that had unprecedented economic and social consequences. It is true that this crisis has its origins in the global economy and has less to do with the post-revolutionary choices concerning the management of the Romanian economy. The forms taken by this financialeconomic crisis are classic: increase in 


\section{Available online at www.managementjournal.info}

unemployment, a drop in the gross internal revenue, the discouragement of investors, social movements, the alarming increase of the budget deficit and of external debt, rising credit rates etc. Among the solution needed to pull out of the economic crisis we have one that by its very nature may lead to economic development, respectively the efficient use of the status of a member state of the European Union, so that Romania may be a clear "beneficiary" of and not a "contributor" to the European budget. Ever since joining the European Union, Romania has taken part as a full member state in the Community Cohesion Policy. Within the framework of this policy, Romania benefits from financial support to help encourage the country's economic development. Theoretically, the volume of available funds is larger than that received by our country through the pre-integration programmes such as PHARE, ISPA and SAPARD. The structural and cohesion funds are financial instruments used by the European Union towards erasing economic and social disparities between regions, with the purpose of firmly establishing economic and social cohesion. Access to the Structural and Cohesion Funds offers Romania the possibility to develop in a balanced manner the regions which are lagging and to modernize the infrastructure and the environment, to support rural development, to create new job opportunities, especially in rural areas, to promote social policies which lead to an increase in the standard of living. In the current European context, the economic development of Romania is possible and through stimulating agriculture, halting all subsidy policies or covering losses, granting pay increases only depending on the growth of work productivity, restarting economic loans through the reduction of credit rates, encouraging national cutbacks which encourage investments in all fields of activity, putting into practice a policy of budget austerity measures which would not allow spending beyond the budget, stimulating export and delivery of goods within the Community, Also, the consolidation

\section{Reference}

1. Dobrotă Niță (1997) Economie politica: o tratare unitara a problemelor vitale ale oamenilor. Editura Economică, Bucuresti.

2. Angelescu Coralia (2000) Economie, editia a 5-a. Editura Economică, Bucuresti.

3. Ciumara Mircea (2008) Economia Naționala a României, editia a 2-a. Editura Independența Economica, Pitesti. and improvement of community institutions and mechanisms specific to market economies, based on the principle of fair competition and social solidarity must become a priority. It represents the basis of a healthy economic development, able to ensure the complete integration of Romania into the European Union, meeting global demands, normal access to resources and international markets, resistance to major economic fluctuations. Sustainable economic development, able of drawing in strategic investments, generating employment and producing resources for social protection, represent the only ways of significantly reducing the disparities that exist between Romania and the European average. This will greatly contribute also to rooting out extreme poverty as a phenomenon, substantially reducing the number of people with lower incomes than the European threshold and reaching a social balance capable of stimulating growth and consolidating the middle classes. Economic development - as the premise of security and wellbeing - decidedly depends on the degree of competitiveness of the nation. Romania may become truly competitive only to the extent that it have society with a strong education, oriented towards attainment of knowledge, capable of valuing its intelligence and creative resources, by starting with the conviction that a well trained and flexible workforce represents an essential condition for a successful European integration and the valuing of opportunities presented by globalization [1-6].

\section{Conclusions}

In conclusion, Romanian national security may be upheld through economic development which can ensure economic prosperity for its citizens, legality, balance and socio-political stability as well as the possibility of living the present with a firm gaze towards the future in the form of favoring environmental security over maximizing profits as a form of development.

4. Trăistaru Ion (1975) Progresul economic. Editura Scrisul românesc, Craiova. p. 12.

5. Academia „Stefan Gheoghiu”, Burtica Cornel, Dobrescu Emilian, Dolgu Gheorghe Editors. (1977) Economia mondială: tipologia economiilor naționale. Editura Politică, Bucureşti. p. 27.

6. http://www.securitatenationala.ro 